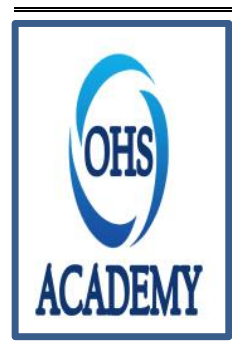

OHS ACADEMY

iş Sağlığı ve Güvenliği Akademi Dergisi

Açık Erişim

Journal of Occupational Health and Safety Academy

Open Access

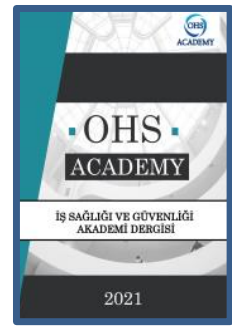

e-ISSN: 2630-578X

\title{
Yükseköğretim Kurumlarının COVID-19 Sürecine Yaklaşımı, İstanbul Örneği
}

\author{
Ahmet ÇABUK ${ }^{1 *}$, Ayşenur YALÇIN ${ }^{2}$, Sena ŞÜLEKOĞLU ${ }^{3}$ \\ ${ }^{1}$ Mülkiyet Koruma ve Güvenlik Bölümü, Meslek Yüksekokulu, Beykoz Üniversitesi, İstanbul, Türkiye \\ ${ }^{2}$ Mülkiyet Koruma ve Güvenlik Bölümü, Teknik Bilimler Meslek Yüksekokulu, Niğde Ömer HALİSDEMİR \\ Üniversitesi, Niğde, Türkiye \\ ${ }^{3}$ Mülkiyet Koruma ve Güvenlik Bölümü, Meslek Yüksekokulu, Beykoz Üniversitesi, İstanbul, Türkiye
}

\begin{abstract}
Makale Tarihçesi
Gönderim: $\quad 07.04 .2021$

Kabul: $\quad 26.04 .2021$

Yayım: $\quad 31.08 .2021$
\end{abstract}

Araştırma Makalesi

\begin{abstract}
Öz- Biyolojik bir tehlike olan SARS-CoV2 kaynaklı COVID- 19 pandemisi can kayıplarına, kalıcı sağlık sorunlarına, sosyal- çalışma- eğitim hayatının kesintiye uğramasına, ülkelerin mikro ve makroekonomisinin bozulmasına ne olmuștur. 11 Mart 2020 tarihinde COVID- 19 salgınında Türkiye'de ilk vakanın açıklanmasıyla Sağlık Bakanlığı bünyesinde oluşturulan Bilim Kurulu tarafindan ilk- orta ve yükseköğretim kurumlarına yönelik olarak 16 Mart 2021 tarihinde eğitime ara verilmesine, 23 Mart 2021 tarihinde ise eğitimin çevrim içi platformlar üzerinden devam edilmesi yönünde karar alınmıştır. Yükseköğretim Kurulu tarafından yükseköğretim kurumlarına eğitim ve öğretim faaliyetleri hakkında önerilerde bulunulmuştur. Yükseköğretim kurumları alınan kararlarına uyarak eğitim ve ögretim faaliyetlerini çevrim içi sistem üzerinden gerçekleştirmek için çalışmalarını yapmış ve salgının önlenmesine bu şekilde katkı sağlamaya çalışmıştır. Mart- Mayıs 2020 tarihleri arasında İstanbul'da faal olan yükseköğretim kurumlarında görev alan öğretim elemanlarına yönelik olarak yükseköğretim kurumlarının COVID-19 salgınına yönelik yaptığı çalışmalar ile birlikte öğretim elemanlarına yönelik yaklaşımlarını belirlemeye yönelik anket uygulaması yapılmıştır. Anket sonuçlarına göre yükseköğretim kurumlarının salgının başladığı tarihten önce ve anketin yapıldığı dönemde öğretim elemanlarına yönelik bilgilendirme ve bilinçlendirmenin yetersiz kaldığı, öğretim elemanlarını yalnız bıraktı̆̆ı, önlem ve tedbirlerde başarısız olduğu belirlenmiştir. Yükseköğretim kurumlarının iç ve dış paydaşlarına yönelik bilinçlendirme ve bilgilendirme çalışmaları yapması salgının yayılmasını önlemek adına direkt ve dolaylı etki gösterecektir. Aynı zamanda bünyesinde görev alan çalışanlarının psikolojik, sosyal ve fiziksel sağlığını takip etmesi ve sağlığın gelişmesine katkı sunacak çalışmalar yapması iș sağlığı ve güvenliği konusunda sorumluluklarını tam olarak yerine getirmesine, topluma ve kamu/ özel işyerlerine iş sağlığı ve güvenliği, çalışanın refahı konularında yol gösterici ve örnek olmasına imkân sağlayacaktır.
\end{abstract}

Anahtar Kelimeler - Biyolojik tehlike, covıd-19, iş sağlı̆̆l ve güvenliği, yüksekögretim kurumu

\section{The Approach of Higher Education Institutions to the COVID-19 Process, The Case of Istanbul}

\author{
Ahmet ÇABUK ${ }^{1 *}$, Ayşenur YALÇIN ${ }^{2}$, Sena ŞÜLEKOĞLU $3^{3 *}$ \\ ${ }^{1}$ Property Protection and Security Department, Vocational School, Beykoz University, İstanbul, Turkey \\ ${ }^{2}$ Property Protection and Security Department, Vocational School of Technical Sciences, Niğde Ömer \\ HALISDEMIR University, Niğde, Turkey \\ ${ }^{3}$ Property Protection and Security Department, Vocational School, Beykoz University, İstanbul, Turkey
}

\footnotetext{
${ }^{1}$ ahmetcabuk@beykoz.edu.tr

Orcid id: 0000-0002-5302-1847

2 ayse.yalcin.651@gmail.com

Orcid id: 0000-0002-7537-6470

3 sulekoglusena@gmail.com

Orcid id: 0000-0001-5667-0394
}

*Sorumlu Yazar / Corresponding Author: ahmetcabuk@ beykoz.edu.tr, Beykoz Üniversitesi, İstanbul/ Türkiye 


\section{Article History}

Received: $\quad 07.04 .2021$

Accepted: 26.04 .2021

Published: $\quad 31.08 .2021$

Research Article

\section{Abstract -}

The COVID-19 pandemic caused by SARS-CoV2, which is a biological hazard, has caused the loss of lives, permanent health problems, interruption of social-working-education life, and the deterioration of the micro and macro economies of countries. March 11, 2020 Date of COVID- 19 outbreaks in Turkey in the first case to explainmade with the creation of the Ministry of Health Sciences by the Board of first- sec-ondary and higher education intitution to for as the interruption of education on March 16, 2021, while on March 23, 2021 train-min cycle it has been decided to continue on internal platforms. The Council of Higher Education made recommendations to higher education institutions about education and training activities. Higher education institutions complied with their decisions and worked to carry out education and training activities through the online system and tried to contribute to the prevention of the epidemic in this way. A questionnaire was applied to determine the approaches of higher education institutions towards the COVID-19 epidemic for the academic staff working in higher education institutions active in Istanbul between March and May 2020. According to the results of the survey, it was determined that higher educa-tion institutions were insufficient to inform and raise awareness of the academic staff before the epidemic started and during the period when the survey was conducted, that they left their teaching staff alone, and they failed in measures and measures. Higher education institutions to raise awareness and inform their internal and external stakeholders will have direct and indirect effects in order to prevent the spread of the epidemic. At the same time, following the psychological, social and physical health of its employees and carrying out activities that will contribute to the development of health, it will ensure that they fulfill their responsibilities in occupational health and safety, society and public / private workplaces on occupational health and safety, employee welfare. it will enable it to be a guide and an example.

Keywords - Biohazard, covid-19, higher education institution, occupational health and safety 


\section{Giriș}

Belirli bir zaman ve bölgede meydana geldiğinde canlı ve cansızların varlığını tehdit eden, sosyal, ekonomik düzen ve etkinlikler, çevre, kültür ve tarih varlıklarına zarar verme ihtimali olan doğal veya yapay fiziksel olay ve olgular tehlike olarak tanımlanmaktadır (AFAD). Dünya ve Türkiye dikkate alındığında deprem, kaya düşmesi, heyelan, çı̆̆, sel, tsunami, erozyon, salgın hastalık, endüstriyel kaza, yıkıcı ve bozucu toplumsal olaylar, terör, siber saldırı, vb. tehlikeler bulunmaktadır.

Jeolojik, coğrafik, kültürel, sosyal vb. özelliklere göre ülkelerde var olan veya dışarıdan gelebilecek tehlikeler değişiklik gösterebilmektedir. Var olan veya dişarıdan gelen tehlikeler riske dönüștüğünde zararlar meydana gelebilmektedir. Riski oluşturan tehlikenin kendisidir. Tehlike kaynă̆ının belirli koşul ve ortamlarda doğurabileceği can, mal, çevresel ve ekonomik gibi değerlerin kaybının gerçekleşme ihtimali risk olarak tanımlanmaktadır (Yönetmelik, 28512). Tehlikeler riske dönüştüğünde zarar meydana gelebilmekte ve fiziksel, sosyal, ekonomik, kültürel, biyolojik unsurlar üzerinde kayıplara neden olmaktadır.

Doğal veya yapay tehlike riske dönüştüğünde ortaya çıkan sonuç afet durumu ya da acil durum olarak tanımlanmaktadır. Doğal veya yapay tehlike riske dönüștüğünde oluşan zarar toplumun tamamını veya bir kısmını fiziksel, ekonomik ve sosyal açıdan etkileyerek normal hayatın akışıı kesintiye uğratıyor ve meydana gelen kesinti yerel toplumun ve destek kuvvetlerinin kapasitesiyle ortadan kaldırllyyorsa bu kriz durumu acil durum olarak tanımlanmaktadır. Ancak normal hayatta kesintiye neden zararlar toplumun baş etme kapasitesini aşıyor ve dışarıdan destek alınıyorsa o zaman yaşanan kriz durumu afet olarak tanımlanmaktadır (AFAD).

Hastalık, canlıların sağlıklı fizyolojik ya da ruhsal yapısını, işlevini ve dengesini değiştiren veya engelleyen belirtileri meydana çıkartan anormal durum olarak tanımlanmaktadır (Demirel, 2019). Salgın hastalık ya da epidemik, dünya üzerinde belirli bir bölgede ortaya çıkıp, yayılarak birden fazla insanın rahatsızlanmasına neden olan hastalık olarak tanımlanmaktadır (Kardaş, 2010). Pandemi, canlı ve cansız varlıkların yaşam alanı olan dünya genelinde ya da belli bir alanda oluşarak, meydana geldiği bölgeyi aşıp, sayıca çok fazla bireyi etkisi altına olan salgın şeklinde tanımlan-maktadır (Öğünç, 2020). Ülkemizde ve tüm ülkelerde hastalığa ne-den olan biyolojik etkenler (Virüs, bakteri vd.) tehlike olarak tanımlanmakta ve acil durum veya afet durumunun meydana gelmesine neden olmaktadır.

Yeni Koronavirüs Hastalığı (COVID-19), ilk olarak Çin'in Vuhan Eyaleti'nde aralık ayının sonlarında solunum yolu belirtileri (ateş, öksürük, nefes darlı̆̆ı) ile kendini göstermektedir. İnsan ve insan dışındaki canlılarda COVID-19'a Sar- CoV- 2 virüsü neden olmaktadır. Tüm dünyada 28 Şubat 2021 tarihi itibariyle toplam tanı sayısı 113.815.816 olup 2.520.550 insan COVID-19 nedeniyle hayatını kaybetmiş ve 64.273.411 kişi iyileşmiştir (Dünya Sağlık Örgütü). Türkiye'de ise tanı konulan insan sayısı 2.646.526, COVID-19 nedeniyle hayatını kaybeden insan sayısı 28.138 ve iyileşen insan sayısı 2.529 .450 'dir (T.C. Cumhurbaşkanlığı). Sar- CoV- 2 virüsünden kaynaklı olarak tüm dünyada başta eğitim ve iş hayatı olmak üzere yaşamın her alanında günlük yaşam kesintiye uğramış ve afet durumu yaşanmaktadır (Sağlık Bakanlığı, 2021).

Türkiye' de aktif olarak eğitim ve öğretim faaliyetini sürdüren devlet üniversitesi sayıs1 129 , vakıf üniversitesi sayısı 74 ve vakıf meslek yüksekokul sayısı 4 olup toplam 207 yükseköğretim kurumu bulunmaktadır. Yükseköğretim kurumlarında eğitim ve öğretim gören öğrenci sayıs1 7.740.502, öğretim elemanı sayısı 166.225 'tir. İstanbul özeline bakıldığında 57 adet yükseköğretim kurumu ve yükseköğretim kurumlarında görev alan 36.896 öğretim elemanı ve eğitim- öğrenim gören 1.109 .739 öğrenci bulunmaktadır (YÖK, 2020). Ülkemizde yükseköğretim kurumları dahil olmak üzere ilk- orta tüm eğitim kurumlarında eğitim ve öğretim faaliyetleri büyük ölçüde uzaktan eğitim (evden öğrenme) şeklinde yapılmaktadır. Covid-19 vakasının tespitiyle ülkemiz-de oluşturulan bilim kurulunun tavsiyesi üzerine yetkili kurum ve kuruluşlar tarafından alınan kararla 16 Mart 2020 tarihinden itibaren örgün eğitim- öğretime ara verilmiş ve yüz yüze eğitimden uzaktan eğitime geçilmiştir. Uzaktan eğitime geçilmesiyle yükseköğretim kurumlarında normal zamanlarda akademik, mesleki ve bireysel gelişime destek olan faaliyetlerde iptal edilmiştir. Eylül 2020 yllında üniversitelerde eğitim ve öğretim faaliyetinin 2020 - 2021 güz döneminde uzaktan eğitim biçiminde olması yönünde Yükseköğretim Kurulu tavsiyede bulunmuştur. Üniversiteler 2020- 2021 y1lı bahar yarıyılında da örgün eğitime ara vermiş ve eğitim- öğretimin uzaktan eğitim şeklinde devam etmektedir.

\section{Materyal ve Yöntem}

Çalışma Mart- Mayıs 2020 tarihleri arasında İstanbul ilinde faaliyet gösteren 57 yükseköğretim kurumunda (Devlet, Vakıf, Vakıfa Bağlı Meslek Yüksekokulu) görev alan öğretim elemanlarına yönelik olarak gerçekleştirilmiştir. Google form üzerinden oluşturulan sorular öğretim elemanlarına ait 19.294 farklı elektronik posta adresine gönderilmiştir. Katılımın artması için öğretim elemanlarına farklı zamanlarda olmak üzere üç (3) 
defa elektronik posta gönderilmiştir. 613 katılımcının verdiği cevaplar müdahale edilmeden bilgisayar ortamına Microsoft Excel vasıtasıyla aktarılmıştır. Sonrasında elde edilen veriler istatistiksel analizin yapılmasına imkân veren IBM SPSS Statistics V23 (Statistical Package for the Social Sciences) programına aktarılmış ve analiz yapılmıştır. Çalışma kapsamında kullanılan anket için Cronbac's Alpha değeri 0,830 olarak belirlenmiştir. Çalışmanın kapsamını oluşturan ve ankette yer alan tanımlayıcı özellikler ile COVID-19'a özel sorulan sorular için edinilen bilgiler tabloya aktarılarak değerlendirilmiştir.

\section{Araştırma Bulguları}

Çalışma kapsamında elde edilen bulgular yaş, medeni durum, eğitim durumu, görev alınan yükseköğretim kurumu, çalışma şekli, görev alınan birim, yükseköğretim kurumunda idari görev durumu, Türkiye' de COVID19 teşhisi konulduğu tarih (11 Mart 2020) öncesinde ilgili virüse ilişkin öğretim elemanlar1- idari personelöğrenci ve ziyaretçilere yönelik bilgilendirme/ eğitim yapılıp yapılmadığı, Türkiye' de COVID-19 teşhisi konulduğu tarih (11 Mart 2020) öncesinde ilgili virüse ilişkin koruma önlem ve tedbirlerin (dezenfektan, hijyen vb.) belirlenerek uygulanıp uygulanmadığı, Türkiye' de COVID-19 teşhisi konulduğu tarih (11 Mart 2020) sonrasında ilgili virüse ilişkin çeşitli yollarla korunma ve önleme özelinde bilgilendirme ve eğitim yapılıp yapılmadığı, Türkiye' de COVID-19 teşhisi konulduğu tarihten (11 Mart 2020) anketi doldurduğunuz güne değin üniversiteniz yetkili kurumları tarafından sağlığınızın takibine yönelik herhangi bir yolla geri bildirim istenip istenmediği, görev alınan üniversitenin COVID-19 salgını kaynaklı acil durum sürecini yönetmekte başarılı olup olmadığı hakkında katılımcılardan elde edilen cevaplar başlıklar halinde verilmiştir.

Öğretim elemanları tarafından verilen cevaplar değerlendirildiğinde yükseköğretim kurumlarının salgının başladığı tarihten önce ve sonrasında salgınla mücadelede topluma yön verecek çalışmalar yapmadığı belirlenmiştir. Özellikle anketin yapıldığı dönem dikkate alındığında salgın öncesinden başlamak üzere öğrenci, öğretim elamanı, idari çalışanlar ile birlikte bulunduğu bölgede yaşayan insanlara bilgilendirme ve bilinçlendirme çalışmaları yapıp yapmadığı, acil ve afet durumlarını yönetmekte konusunda plan ve stratejilerinin olup olmadığı, başta varlık sebebini oluşturan öğrenciler ile birlikte öğretim elemanı ve idari çalışanların Bedensel- psikolojik- sosyal yönden sağlık durumlarının iyi olması ve korunmasına yönelik örnek olabilecek çalışmalar yapıp yapmadığına dair sonuçlar elde edilmiştir.

\section{Yaş}

Çalışmaya katılan öğretim elemanlarının yaş dağılımları tabloda verilmiştir. Çalışmaya katılan öğretim elemanlarının yaş dağılımına bakıldığında 20- 30 yaş aralığındaki öğretim elemanı sayısının 138 (\%22,5), 31-40 yaş aralığındaki öğretim elemanı sayısının 158 (\%25,8), 41-50 yaş aralığındaki öğretim elemanı sayısının 159 (\%25,9), 51-60 yaş aralığındaki öğretim elemanı sayısının $143(\% 23,3)$ ve 65 ve üstü yaş aralığındaki öğretim elemanı sayısının $15(\% 2,4)$ olduğu görülmektedir.

Tablo 3.1. Yaş Dağılımı

\begin{tabular}{|l|l|c|c|}
\hline \multirow{2}{*}{ Yaş } & \multicolumn{1}{|c|}{ Dağılım } & Sayı (Adet) & Yüzde (\%) \\
\cline { 2 - 4 } & $20-30$ & 138 & 22,5 \\
\cline { 2 - 5 } & $31-40$ & 158 & 25,8 \\
\cline { 2 - 4 } & $41-50$ & 159 & 25,9 \\
\cline { 2 - 4 } & $51-65$ & 143 & 23,3 \\
\cline { 2 - 4 } & $>65$ & 15 & 2,4 \\
\hline
\end{tabular}

\section{Medeni Durum}

Ankete katılan öğretim elemanlarının medeni durum dağılımları aşağıdaki tabloda gösterilmiştir. Çalışmaya katılan öğretim elemanlarından bekar olanların sayısı $369(\% 60,2)$ ve evli olanların sayısı 244'tür $(\% 39,8)$. 
Tablo 3.2. Medeni Durum Dağılımı

\begin{tabular}{|l|l|l|l|}
\hline \multirow{4}{*}{ Medeni Durum } & \multirow{2}{*}{ Durum } & Sayı (Adet) & Yüzde (\%) \\
\cline { 2 - 4 } & Bekar & 369 & 60,2 \\
\cline { 2 - 4 } & Evli & 244 & 39,8 \\
\hline
\end{tabular}

\section{Eğitim Durumu}

Ankete katılan öğretim elemanlarının eğitim durumu dağılımları aşağıdaki tabloda gösterilmiştir. Çalışmaya katılan öğretim elemanlarından lisans mezunu olanların sayısı $19(\% 3,1)$, yüksek lisans mezunu olanların sayısı $158(\% 25,8)$, doktora mezunu olanların sayısı 436’ür $(\% 71,1)$.

Tablo 3.3. Eğitim Durumu Dağılımı

\begin{tabular}{|l|l|l|l|}
\hline \multirow{5}{*}{ Eğitim Durumu } & Durum & Sayı (Adet) & Yüzde (\%) \\
\cline { 2 - 4 } & Lisans & 19 & 3,1 \\
\cline { 2 - 4 } & Yüksek Lisans & 158 & 25,8 \\
\cline { 2 - 4 } & Doktora & 436 & 71,1 \\
\hline
\end{tabular}

\section{Görev Alınan Yükseköğretim Kurumu}

Ankete katılan öğretim elemanlarının görev alınan yükseköğretim kurumu dağılımları aşağıdaki tabloda gösterilmiştir. Çalışmaya katılan öğretim elemanlarından devlete bağlı üniversitede görev alanların sayısı 343 $(\% 56,0)$, vakıfa bağlı üniversitede görev alanların sayısı 270’tir (\%44,0).

Tablo 3.4. Görev Alınan Yükseköğretim Kurumu Dağılımı

\begin{tabular}{|l|l|l|l|}
\hline \multirow{2}{*}{ Görev Alınan Yükseköğretim Kurumu } & Durum & Sayı (Adet) & Yüzde (\%) \\
\cline { 2 - 4 } & Devlet Üniversitesi & 343 & 56,0 \\
\cline { 2 - 4 } & Vakıf Üniversitesi & 270 & 44,0 \\
\hline
\end{tabular}

\section{Çalıșma Şekli}

Ankete katılan öğretim elemanlarının 589’u (\%96,1) tam zamanlı, 14’ü $(\% 2,3)$ yarı zamanlı, 10’u $(\% 1,6)$ ders saat ücretli olarak yükseköğretim kurumlarında görev almaktadır.

Tablo 3.5. Öğretim Elemanlarının Çalışma Şekli

\begin{tabular}{|l|l|l|l|}
\hline \multirow{4}{*}{ Çalışma Şekli } & \multirow{2}{*}{ Şekil } & Sayı (Adet) & Yüzde (\%) \\
\cline { 2 - 4 } & Tam Zamanlı & 589 & 96,1 \\
\cline { 2 - 4 } & Yarı Zamanlı & 14 & 2,3 \\
\cline { 2 - 4 } & Ders Saat Ücretli & 10 & 1,6 \\
\hline
\end{tabular}

\section{Çalışma Şekli}

Ankete katılan öğretim elemanlarının 589'u (\%96,1) tam zamanlı, 14’ü $(\% 2,3)$ yarı zamanlı, 10'u $(\% 1,6)$ ders saat ücretli olarak yükseköğretim kurumlarında görev almaktadır.

Tablo 3.6. Öğretim Elemanlarının Görev Aldıkları Birim

\begin{tabular}{|l|l|l|l|}
\hline \multirow{5}{*}{ Görev Alınan Birim } & Durum & Sayı (Adet) & Yüzde (\%) \\
\cline { 2 - 4 } & Rektörlük & 33 & 5,4 \\
\cline { 2 - 4 } & Enstitü & 18 & 2,9 \\
\cline { 2 - 4 } & Fakülte & 437 & 71,3 \\
\cline { 2 - 4 } & Yüksekokul & 41 & 6,7 \\
\cline { 2 - 4 } & Meslek Yüksekokulu & 84 & 13,7 \\
\hline
\end{tabular}




\section{Görev Aldığı Birimde İdari Görev}

Ankete katılan öğretim elemanlarının 198'inin (\%32,3) idari görevinin var olduğu, 415'inin (\%67,7) idari görevinin olmadığı gözlemlenmiştir.

Tablo 3.7. Görev Aldığı Birimde İdari Görev

Görev Aldığı Birimde İdari Görev

\begin{tabular}{|l|l|l|}
\hline Durum & Sayı (Adet) & Yüzde (\%) \\
\hline Var & 198 & 32,3 \\
\hline Yok & 415 & 67,7 \\
\hline
\end{tabular}

Türkiye' de COVID- 19 Teşhisi Konulduğu Tarih (11 Mart 2020) Öncesinde İlgili Virüse İlişkin Öğretim Elemanları- İdari Personel- Öğrenci ve Ziyaretçilere Yönelik Bilgilendirme/ Eğitim

Yükseköğretim kurumları tarafından 11 Mart 2020 öncesinde COVID- 19 hakkında öğretim elemanları- idari personel- öğrenci ve ziyaretçilere yönelik olarak $370(\% 64,6)$ öğretim elemanı bilgilendirme yapıldığını/ eğitim verildiğini belirtirken $203(\% 35,4)$ öğretim elemanı bilgilendirme yapılmadığını/ eğitim verilmediğini, 89 $(\% 14,5)$ öğretim elemanı bilgilendirme yapılıp yapılmadığı/ eğitim verilip verilmediği hakkında bilgisinin olmadığını belirtmiştir.

Tablo 3.8. 11 Mart 2020 öncesinde COVID- 19 hakkında öğretim elemanları- idari personel- öğrenci ve ziyaretçilere yönelik bilgilendirme/ eğitim durumu

\begin{tabular}{|l|l|l|l|}
\hline \multirow{4}{*}{ Bilgilendirme ve Eğitim } & Durum & Sayı (Adet) & Yüzde (\%) \\
\cline { 2 - 4 } & Evet & 251 & 40,8 \\
\cline { 2 - 4 } & Hayır & 273 & 44,5 \\
\cline { 2 - 4 } & Bilmiyor & 89 & 14,5 \\
\hline
\end{tabular}

İşveren/ işveren vekili acil durum ve afet durumunun oluşmasına neden olabilecek tehlikeler hakkında çalışan ile çalışma çevresini etkileyecek tehlikelerin önlenmesi veya sınırlandırılması için tehlikeleri önceden değerlendirmeli ve önleyici ve sınırlayıcı tedbirleri almalıdır. Önleyici ve sınırlayıcı tedbirlerle birlikte acil durum ve afet durumları ve bu durumların meydana gelmesine neden olan tehlike hakkında bilgilendirme yapmalıdır (Yönetmelik, 28681). Anket sonucu değerlendirildiğinde yükseköğretim kurumlarının bilgilendirme ve bilinçlendirme konusunda öğretim elemanlarının tamamının bilgilendirmediği belirlenmiştir.

Türkiye' de COVID- 19 Teşhisi Konulduğu Tarih (11 Mart 2020) Öncesinde İlgili Virüse İlişkin Öncesinde İlgili Virüse İliş̧kin Koruma Önlem ve Tedbirlerin (Dezenfektan, Hijyen vb.) Belirlenerek Uygulanması

Öğretim elemanlarından 294'ü (\%48,0) yükseköğretim kurumları tarafindan 11 Mart 2020 öncesinde COVID19 için koruma önlem ve tedbirlerinin (dezenfektan, hijyen vb.) belirlenerek uygulandığını, 202'si (\%33,0) belirlenip uygulanmadığını, 117'si $(\% 19,1)$ belirlenip belirlenmediği ve uygulanıp uygulanmadığını bilmediğini belirtmiştir.

Tablo 3.9. 11 Mart 2020 öncesinde COVID- 19 için koruma önlem ve tedbirlerin (dezenfektan, hijyen vb.) belirlenerek uygulanması

\begin{tabular}{|l|l|c|c|}
\hline \multirow{4}{*}{ Önlem ve Tedbir } & \multicolumn{1}{|c|}{ Durum } & Sayı (Adet) & Yüzde (\%) \\
\cline { 2 - 4 } & Evet & 294 & 48,0 \\
\cline { 2 - 4 } & Hayır & 202 & 33,0 \\
\cline { 2 - 4 } & Bilmiyor & 117 & 19,1 \\
\hline
\end{tabular}

İşveren/ işveren vekili tarafından acil durum ve afet durumlarına neden olan tehlikenin türüne göre müdahale yöntemlerinin belirlenmesi ve müdahale yöntemlerinin yazılı hale getirilmesi, tehlikenin olumsuz etkisinden korunmak amacıyla önleyici ve sınırlayıcı tedbirler alması, acil durum müdahale ekiplerinin oluşturulması ve acil duruma neden olacak tehlike özelinde müdahale ekibine gerekli eğitimleri vermesi gerekmektedir (Yönetmelik, 28681). Yükseköğretim kurumlarının COVID-19 salgınına yönelik olarak gerekli önlemleri almada yetersiz kaldığı görünmektedir. Dezenfektan ve sterilizasyon işlemlerinin yapılmadığı, yükseköğretim kurulu tarafından alınan karara kadar uluslararası etkinliklere devam edildiği ve yurtdışına gidip gelen 
akademisyenlerin karantina sürecine alınmadığı, COVID-19 özelinde ekiplerin ve acil durum planı oluşturulmadığı belirlenmiştir.

Türkiye' de COVID- 19 Teşhisi Konulduğu Tarih (11 Mart 2020) Sonrasında İlgili Virüse İlişkin Öğretim Elemanları- İdari Personel- Öğrenci ve Ziyaretçilere Yönelik Bilgilendirme/ Eğitim

Yükseköğretim kurumları tarafından 11 Mart 2020 sonrasında COVID- 19 hakkında öğretim elemanlar1- idari personel- öğrenci ve ziyaretçilere yönelik olarak 389 (\%63,5) öğretim elemanı bilgilendirme yapıldı̆̆ını/ eğitim verildiğini belirtirken $142(\% 23,2)$ öğretim elemanı bilgilendirme yapılmadığını/ eğitim verilmediğini, 82 $(\% 13,4)$ öğretim elemanı bilgilendirme yapılıp yapılmadığı/ eğitim verilip verilmediği hakkında bilgisinin olmadığını belirtmiştir.

Tablo 3.10. 11 Mart 2020 sonrasında COVID- 19 hakkında öğretim elemanları- idari personel- öğrenci ve ziyaretçilere yönelik bilgilendirme/ eğitim durumu

\begin{tabular}{|l|l|l|l|}
\hline \multirow{4}{*}{ Bilgilendirme ve Eğitim } & Durum & Sayı (Adet) & Yüzde (\%) \\
\cline { 2 - 4 } & Evet & 389 & 63,5 \\
\cline { 2 - 4 } & Hayır & 142 & 23,2 \\
\cline { 2 - 4 } & Bilmiyor & 82 & 13,4 \\
\hline
\end{tabular}

Yükseköğretim kurumlarında Türkiye'de ilk vakanın tespitinden sonraki süreçte öğretim elemanı, idari personel, öğrenci ve ziyaretçilere yönelik bilgilendirme ve bilinçlendirme çalışmasının yapıldığı görülmektedir. Ancak çalışmanın yeterli olmadığı ve bilinçlendirme/ bilgilendirmede eksik kalındığı görülmektedir.

Türkiye' de COVID- 19 Teşhisi Konulduğu Tarihten (11 Mart 2020) Anketi Doldurduğunuz Güne Değin Üniversiteniz Yetkili Birimleri Tarafından Sağlığınızın Takibine Yönelik Herhangi Bir Yolla Geri Bildirim Yapılması

Yükseköğretim kurumları tarafından 11 Mart 2020 tarihinden katılımcı tarafından anketin doldurulduğu güne değin üniversite yetkili birimleri tarafından öğretim elemanın sağlığının takibine yönelik olarak herhangi bildirim yapılıp yapılmadığı hakkında soru yönlendirilmiştir. Öğretim elemanlarından 163'ü $(\% 26,6)$ yetkili birim tarafından arandığını, 390’ı $(\% 63,6)$ herhangi bir şekilde aranmadığını, 60’ı $(\% 9,8)$ bilmediğini belirtmiştir.

Tablo 3.11. 11 Mart 2020 sonrasında COVID- 19 özelinde yükseköğretim kurumu yetkili birimi tarafından çalışanların sağlığının takip edilmesi

\begin{tabular}{|l|l|l|l|}
\hline \multirow{4}{*}{ Takip } & Durum & Sayı (Adet) & Yüzde (\%) \\
\cline { 2 - 5 } & Evet & 163 & 26,6 \\
\cline { 2 - 5 } & Hayır & 390 & 63,6 \\
\cline { 2 - 4 } & Bilmiyor & 60 & 9,8 \\
\hline
\end{tabular}

Yükseköğretim kurumlarının salgın döneminde çalışanların sağlığını takip etmediği belirlenmiştir. Bu dönemde öğretim elemanlarının maaşında kesinti yapıldığı, yıllık izinlerin zorla kullandırıldığı, yemek kartı ve diğer yan hakların verilmediği, İlgili soruya verilen cevaplar değerlendirildiğinde bazı yükseköğretim kurumlarında fakülte dekanlığı ve bölüm başkanlığı düzeyinde öğretim elemanlarının sağlık durumlarının ara ara takip edildiği, mesajlaşma uygulaması üzerinden fakülte bazında bilgilendirmeler alındığı, üniversitenin COVID-19 için özel bir portal oluşturduğu ve bilgilendirmelerin personel tarafından girilmesine imkan sağlanarak bu şekilde takibin yapıldığı belirtilmiştir.

Görev Aldığınız Üniversite COVID- 19 Salgını Kaynaklı Acil Durum Sürecini Yönetmekte Başarı Durumu

Yükseköğretim kurumunun COVID-19 Salgını kaynaklı acil durum sürecini yönetmekte başarı durumu hakkında öğretim elemanlarından 391'i $(\% 63,8)$ başarılı olduğunu, 65'i $(\% 10,6)$ başarısız olduğunu, 12'si $(\% 2,0)$ kısmen başarılı olduğunu, 145 'i $(\% 23,7)$ başarılı olup olmadığı konusunda bilgi sahibi olmadığını belirtmiştir. 
Tablo 3.12. Görev alınan üniversitenin COVID-19 Salgını kaynaklı acil durum sürecini yönetmekteki başarı durumu

\begin{tabular}{|l|l|l|l|}
\hline \multirow{4}{*}{ Başarı } & Durum & Sayı (Adet) & Yüzde (\%) \\
\cline { 2 - 4 } & Evet & 391 & 63,8 \\
\cline { 2 - 4 } & Hayır & 65 & 10,6 \\
\cline { 2 - 4 } & Kismen & 12 & 2,0 \\
\cline { 2 - 4 } & Bilmiyor & 145 & 23,7 \\
\hline
\end{tabular}

Ülkeleri etkileyen COVID-19 salgınının olumsuz etkilerinin açık ve görünür olmasına rağmen yükseköğretim kurumlarının yükseköğretim kurulu tarafından alınan karara kadar özellikle bir çalışma yapmadığı sonrasında ise yalnızca yükseköğretim kurulu tarafından tavsiye edilen kararları uyguladığı belirtilmiştir. Yükseköğretim kurumlarının diğer ülkeleri takip etmediği için acil durum planı oluşturmadığı ve bu nedenle öğretim elemanlarının ve öğrencilerin mağdur edildiği belirtilmiştir. Özellikle öğrencilerin kaldığı yurtların birden tahliye edilmesi kararı alınarak öğrencilerin mağdur edilmesinin acil durum hazırlığının olmadığının kanıtı olarak gösterilmiştir. Önlem alınmamasına karşın öğretim elemanları dahil tüm çalışanların üniversiteye gitmeye zorlandığı ve bunun için imza alındığ üniversiteye çağrıldığı, başka bir üniversitede evden çalışmaya diğer üniversitelere nazaran geç başlandığı ve eğitim ve öğretimin üniversiteden devam edildiği belirtilmiştir.

\section{Tartışma ve Sonuç}

Biyolojik bir tehlike olan SARS-CoV2 kaynaklı COVID-19 (Yeni Korona Virüs Hastalığı) pandemisi, ülkemiz dahil olmak üzere birçok ülkede can kayıplarına, kalıcı sağlık sorunlarına neden olmasının yanında sosyal, ekonomik yönden hayatı etkilemiştir ve tüm dünyayı etkileyen bir afet durumunun yaşanmasına neden olmuştur (Tercan, 2020). İşyerlerinde acil durumlar hakkındaki yönetmelik gereği afet durumunun kontrol edilmesi, koruyucu, önleyici ve sınırlayıcı tedbirlerin alınması, tüm paydaşların afet ve acil duruma neden olan tehlikelerden korunması ve risklerin önlenmesi için yükseköğretim kurumları dahil tüm işyerlerinin acil durum planlarının işler ve çalışır durumda olması gerekmektedir (Yönetmelik, 2013). Türkiye'de 129'u devlet 74'ü vakıf 4'ü vakıf meslek yüksekokulu olmak üzere toplam 207 yükseköğretim kurumu bulunmaktadır. Yükseköğretim kurumları hem yerleşkeleri hem de sınırdaş oldukları diğer yapılarla büyük bir yaşayan ekosistem oluşturmaktadır. Yükseköğretim kurumlarında 3.002.964'ü ön lisans, 4.538.926'sı lisans, 297.001'i yüksek lisans, 101.242'si doktora seviyesinde olmak üzere 7.940.133 öğrenci eğitim ve öğrenim görmekte ve 179.775 öğretim elemanı görev almaktadır (YÖK, 2021). Ayrıca yükseköğretim kurumlarında eğitim ve öğretim faaliyetleri dışındaki çalışma faaliyetlerini yürüten çalışanlar, alt işverenler bulunmakla birlikte günlük olarak ziyaretçi alan ve yerleşkenin bulunduğu ve sınırdaş olduğu alanda yaşayan insanlarla birlikte canlı ve cansız varlıklar bulunmaktadır. Bu sebeple insan sayısından yoğun bir popülasyona sahip olan üniversitelerin her türlü tehlike ve tehlikeden kaynaklı riskleri göz önüne alarak acil durum planlarını hazırlamaları ve her zaman çalışır halde bulundurmaları gerekmektedir.

Tüm Dünya'da olduğu gibi ülkemizde de COVID-19 hastalığının etkeni olan SARS- CoV2'nin yayılımı nedeniyle ilk- orta ve yüksek öğrenim seviyesinde yüz yüze eğitime ara verilmiş ve çevrim içi eğitime geçilmiştir. Ülkemizde Yükseköğretim kurulu tarafında 06 Mart 2020 tarihinde üniversitelere seyahat, yurtdış1 toplantılar, uluslararası katılımlı toplantılar konusunda alınması gereken tedbirler konusunda öneriler verilmiştir. $\mathrm{Bu}$ tarihte üniversitelere özellikle yükseköğretim kurumlarına ait yerleşkelerde temizliğe dikkat edilmesi, özellikle ortak kullanım alanlarında görünür yerlere kişisel hijyen kuralları hakkında bilgi veren görsellerin yerleştirilmesi ve broşürlerin dağıtılması, yerleşkelerde bulunan herkese COVID-19 bulaşma yolları ve korunma yöntemlerine ilişkin hatırlatma ve bilgilendirmelerin yapılması, el dezenfektanlarının bulundurulması ve el dezenfektanlarının erişilebilir alanlara konulması önerilmiştir (YÖK, 2020).

Yükseköğretim Kurulu tarafından 13 Mart 2020 tarihli Koronavirüs (Covid-19) Bilgilendirme Not:1'de yükseköğretim kurumlarında 16 Mart 2020 tarihinden itibaren 3 hafta süreyle eğitime ara verilmiştir. Bu süre içerisin-de belirli görevler dışında yer alan 60 yaş ve üzerinde yaşta olanlar, süt izni kullanan anneler, bağışıklık sorunu olanlarla birlikte kronik hastalıkları (Kanser, solunum yolu hastalıkları, obezite, diyabet, kalp ve damar hastalıkları) olan kişilerle idari izinli sayılmış, akademik ve idari personelin yurtdışı çıkışları ile birlikte tüm eğitim- öğretim, akademik değişim programları, sosyal ve kültürel faaliyetler, spor müsabakaları gibi yurtiçi ve yurtdışı tüm faaliyetler iptal edilmiştir (YÖK, 2020).

Yükseköğretim Kurulu tarafından 13 Ağustos 2020 tarihli Yükseköğretim Kurumlarımızdaki 2020-2021 Eğitim ve Öğretim Dönemine Yönelik Açıklama 'da ise küresel salgından dolayı tüm dünyada 20 milyondan fazla kişinin enfekte olduğu, 700 binden fazla kişinin hayatını kaybettiği belirtilmiş ve bu durumun yükseköğretimi de etkilediği ve uzun vadeli yeni önlemlere ihtiyaç duyulduğu belirtilmiştir (YÖK, 2020). Yükseköğretim kurulu 
tarafından yapılan açıklama ile Türkiye'de birçok üniversite eğitim ve öğretime çevrim içi platformlardan devam etme kararı almış ve bu karar bahar döneminde de uygulanmaktadır.

T.C. Aile, Çalışma ve Sosyal Hizmetler Bakanlığı tarafından yayınlanan rehberlerde, COVID-19 hastalığına neden olan SARS-CoV2 etkenini taşıyan kişilerin öksürmesi veya hapşırması sonucunda ortaya çıkan damlacıkların direkt veya dolaylı olarak diğer insanların ağız, burun ve gözlerine temas etmesi sonucu bulaştığ belirtilmiştir. Bu nedenle özellikle insanların yoğun ve birlikte olduğu yerlerde temizlik, maske ve fiziki mesafe kurallarına uyulması ve bu konuda eğitimler ve bilgilendirmelerin yapılması, gerekli tedbirler alınması önerilmiştir (AÇSH, 2021). Yükseköğretim kurumları bünyelerinde eğitim ve öğretim faaliyetlerinin yapılmasına imkân sağlayan derslik, atölye, laboratuvar, amfileri, bilimsel, sosyal, sanatsal faaliyetlerin gerçekleştirildiği alanları, idari, teknik ve diğer işlerin yapıldı̆̆ı mekanları içermektedir. Bu alanlar insanların yoğun ve birlikte bulunduğu alanlar olması nedeniyle bakanlık tarafından yapılan önerilerin dikkate alınarak gerçekleştirilmesi hastalığın yayılmasının önlenmesine katkı sağlayacaktır.

Ülkemizde işyerleri iş sağlığı ve güvenliği hizmetlerinin daha etkin olması amacıyla işyerinde yapılan asıı iş, yapılan işin özelliği ile birlikte işin yapımının her safhasında kullanılan veya ortaya çıkan ham madde, madde, ürün, üretimin yöntemi ve yapılış şekilleri, işin yapıldığı ortamın koşul ve şartları dikkate alınarak sosyal tarafların dahil olduğu komisyon görüşleri ile tehlike sınıflarına ayrılmıştır. İşyerleri tehlike sınıflarına göre az tehlikeli, tehlikeli ve çok tehlikeli sınıf kategorilerine ayrılmıştır (Uçan, 2021). Yükseköğretim kurumları eğitim ve öğretimin gerçekleştirildiği alanlar olmakla birlikte eğitim- öğretim ve idari işlerin yapılmasında görev alan kişiler için çalışma alanı yani işyeri olup az tehlikeli sınıfta yer almaktadır. İşyerinin içinde bulunduğu tehlike sınıfı dikkate alınarak tüm çalışanlara iş sağlığı ve güvenliği eğitimi verilmektedir. İşe yeni başlayanlara fiili olarak işe başlamadan önce ve işe başladıktan kısa süre sonra eğitimler verilmektedir. Eğitimler tehlike sınıfına göre periyodik sürelerde, değişen şartlara ve çalışma şartlarına bağlı olarak yeni risklerin ortaya çıkması durumunda çalışanlara verilmektedir. Çalışanlara verilen iş sağlığ 1 ve güvenliği eğitimleri genel, sağlık ve teknik konularını içermektedir (Yönetmelik, 28648). COVID-19 hastalığı biyolojik afet durumu olarak değerlendirilmesinin yanı sıra SARS-CoV2 virüsünden kaynaklı riskin ortaya çıkması tüm işyerlerinde çalışanlara yönelik konu hakkında eğitim verilmesi gerekliliğini ortaya çıkarmıştır. Yönetmelik gereğince ve Yükseköğretim Kurulu tarafından yayınlanan tavsiye kararları gereğince yükseköğretim kurumlarında sağlık, emniyet ve güvenliğin sağlanması için akademik personel dahil tüm çalışanlara eğitim verilmesi ve yerleşkelerde önlem ve tedbirlerin ivedilikle uygulanması gerekliliği ortaya çıkmıştır.

Türkiye'de COVID-19 teşhisi konulduğu tarihten anketin doldurulduğu güne değin üniversite yetkili birimleri tarafından çalışanların sağlığının takibine yönelik herhangi bir yolla geri bildirim yapılmamasının oranı \% 73,4 olarak belirlenmiştir. İçinde bulunulan süreçte yerli ve yabancı menşeli şirketler çalışanlarının ve çalışanların ailelerinin sağlı̆̆nı takip etmiş, çevrim içi platform üzerinden psikolog, diyetisyen vb. uzmanlar vasıtasıyla ergonomi, çocuk ve yetişkin ruh sağlığı, sağlıklı beslenme, sağlıklı egzersiz ve yaşam destekleri sağlamıştır. Aynı zamanda şirketler tarafından çalışanların evden çalışmalarında ergonomi yönünden rahat çalışmalarına imkân sağlamak için çalışanların koltuk ve ihtiyaçları olan diğer iş yeri malzemelerini almaları için maddi katkı sağlanmış, çalışanların iş yerlerinde kullandıkları koltukları evlerine götürmelerine izin verilmiştir. Yükseköğretim kurumlarında yaşanılan süreç dikkate alındığında çalışanların ve çalışanların sağlığının takibine yönelik olarak topluma ve kamu/ özel iş yerlerine örnek olacak çalışmalara yer verilmemiştir. Özellikle yarı zamanlı ve ders saat ücreti alarak yükseköğretim kurumlarında öğretime katkı sunan öğretim elemanlarının iş sözleşmeleri yükseköğretim kurumları tarafından tek taraflı olarak feshedilmiştir. Öğretim elemanları ve idari çalışanların iş yükleri arttırılmış, çevrim içi platform üzerinden aktif çalışmaya devam eden tüm çalışanların yıllık izinleri uygunsuz bir şekilde istekleri dışında kullandırılmış, yükseköğretim kurumlarına gelmeleri ve çalışmalarını buralardan yürütmeleri istenmiştir. Özellikle ulaşımda toplu taşıma kullanan çalışanların tehlikeye açık olmasına karşın görev yerlerine gelmeleri istenmiştir. Anketin tamamlandığı haziran ayından sonraki geri dönüşlerde özellikle vakıf üniversitelerinde tercih dönemi içerisinde temmuz- ağustos ve eylül aylarında öğretim elemanı, idari personelin yükseköğretim kurumu tanıtım ve tercihlerinde görev alması istenmiştir. Yeterli önlem ve tedbirler alınmadan tüm çalışanların bu dönemde yoğun çalışması çalışanların fiziksel, ruhsal ve sosyal yönden zarar görmesine ve aynı zamanda hastalık etkeninin yayılmasına neden olunmuştur. Yükseköğretim kurumlarının tanıtım ve tercih dönemlerinde tüm çalışanlara yönelik COVID-19 ile ilgili eğitim verilmemiş ayrıca yükseköğretim kurumlarına gelen aday öğrencilere ve onlarla birlikte gelen yakınlarına bilgilendirmeler yapılmamıştır.

Ankete verilen diğer cevaplara bakıldığın bazı yükseköğretim kurumlarının COVID-19 sürecinde öğrenciler ile birlikte tüm çalışanların fiziksel, ruhsal ve sosyal yönden iyilik hallerini korumak üzere çalışmalar yaptığı belirlenmiştir. COVID-19 hastalığına ilişkin tüm korunma yollarının yükseköğretim yönetimi tarafindan öğrenciler ve çalışanlara uzaktan eğitim ve bilgilendirme yoluyla aktarıldığı, öğretim elemanlarının kendi dersleri kapsamında öğrencilere yönelik bilgilendirmeler yaptığı, yerleşkeler içerisinde bulunan binalara el 
koruyucu dezenfektan bulundurulduğu ve binalarda rutin dezenfeksiyon işleminin yapıldığı belirtilmiştir. Bazı yükseköğretim kurumlarının çalışanlarının sağlık durumlarını sürekli olarak kontrol ettiği, takip için resmi internet siteleri üzerinde portal oluşturularak takip ve bilgilendirmeler yapıldığı, mesajlaşma uygulama uygulamaları üzerinden dekanlık ve bölüm başkanlığı seviyesinde sürekli çalışanlarla iletişim kurulduğu ve takibin yapıldığı belirtilmiştir. Özellikle hastaneleri olan üniversitelerin COVID-19 salgınına yönelik olarak acil durumu yönetmekte başarılı olduğu öğretim elemanları tarafından belirtilmiştir.

COVID-19 sürecinde yükseköğretim kurumlarında çalışanlar dahil olmak üzere kamu/ özel iş yerlerinde görev alan çalışanların yönetime bağlı birim ve kişiler tarafından çeşitli yollarla çalışanların fiziksel, ruhsal ve sosyal yönden sağlık durumlarının takip edilmesi çalışanların iyilik halinin korunması açısından önemlidir. Çalışmanın yapıldığı yer ve zamandan bağımsız olarak çalışanların sağlığını ve güvenliğini korumaya yönelik yapacağ çalışmalar (Maaş iyileştirmesi, çalışma süresinde kısaltma, mobilya ve iş araçları desteği, uzaktan sosyal ve psikolojik destek, dinlenme ve tatil haklarında iyileştirme vb.) çalışanların, çalışanlarla birlikte ailelerin, ailelerle birlikte toplumun, toplumla birlikte ülkenin sosyal ve ekonomik yönden refahının sağlanması ve hayatın her alanında (Evde, işte, sosyal yaşamda) refahın sürdürülebilir olmasına imkan sağlayacaktır. Bu kapsamda kamu ve özel işyerlerine örnek olacak yükseköğretim kurumlarının tüm iç ve dış paydaşları dikkate alarak iç ve diş mekanlarda sosyal yaşam mekanlarının oluşturulması, her alanda sportif faaliyetlere destek olması ve kaynak paylaşımını her spor faaliyetini destekleyecek şekilde yapması, yükseköğretim kurumlarının erişebilir olması için çalışmalar yapması, çevreyi tüm unsurlarıyla kabul ederek odağına tüm canlı ve cansız varlıkları alarak hareket etmesi, çalışma şekli ve görevler dikkate alınmadan işveren dahil tüm çalışanlara eşit ve adaletli yaklaşım sergilenerek görev ve sorumluluk fark etmeksizin tüm çalışanların fiziksel, ruhsal ve sosyal yönden iyilik hallerinin takip edilmesi hem içinde bulunulan süreç hem de normal zaman içerisinde çalışma ortamı kalitesinin artmasına ve direkt olarak kişilerin yaşam kalitesinin artmasına imkan sağlayacaktır. Yükseköğretim kurumlarında makam, mevki ve kadro fark etmeksizin görev alan tüm kişilerin çalışanlar olarak kabul edilmesi mobbing başta olmak üzere psikososyal risk etmenlerinin ortadan kaldırılmasının yanından alınacak önlem ve tedbirlerle tüm risk etmenlerinin ortadan kaldırılmasıyla fiziksel, ruhsal ve sosyal açıdan tüm işyerlerine örnek olması ve takip edilmesi sağlanabilecektir.

Yapılan anket çalışması dikkate alındığında yükseköğretim kurumlarında öğretim elemanlarının büyük bir çoğunluğuna COVID-19 hastalığı, hastalık etkeninden korunması ve hastalık durumunda yapılması gerekenler hakkında eğitim verilmediği, yerleşkelerde önlem ve tedbirlerin yeterince alınmadığ 1 ve uygulanmadığ1, öğrencilere ve ziyaretçilere aynı şekilde eğitim verilmediği belirlenmiştir. Afet ve acil durumlara yönelik plan ve stratejisinin olmadığı ve süreci yönetmekte başarısız olduğu görülmüştür. Aynı zamanda süreç içerisinde yükseköğretim kurumları öğrenciler başta olmak üzere öğretim elamanı ve idari personel yalnız bırakılmıştır. Mevcut durumda asıl işi eğitim ve öğretim faaliyeti olan yükseköğretim kurumlarının eğitim ve öğretim faaliyetlerinin uzaktan yürütülmesine rağmen öğretim elemanı ile birlikte diğer çalışanların yükseköğretim kurumuna gelmesinin istenmesi, çalışma alanlarında gerekli önlemlerin alınmaması vakaların artmasına ve yayılmasına neden olmaktadır. Bu sonuçlara bakıldığında yükseköğretim kurumları iş sağlığı ve güvenliği, afet ve acil durum planlaması, topluma örnek olmak ve yönlendirme, teknoloji ve altyapı, insan refahı başlıklarında başarısız olmuştur.

Yükseköğretim kurumları eğitim ve öğretimin uygulandığı yerler olmakla birlikte ülkenin ekonomik, sosyal ve bilimsel açıdan gelişmesi, toplumun bilgi ve kültür açısından farkındalığının arttırılmasını yönünde çalışmalar yapması varlığının oluştuğu andan itibaren görev ve sorumluluğudur. Bu sebeple toplumu ilgilendiren her konuda yükseköğretim kurumlarının örnek olması, yönlendirici olması, bilgi ve teknoloji üretmesi, lider olması ve kendisine atfedilen görevlerde sorumlukları yerine getirmesi, bulunduğu bölgede sosyal ve çalışma hayatının gelişmesine katkı sunması gerekmekte ve kendisinden beklenmektedir.

\section{Kaynaklar}

Afet ve Acil Durum Yönetim Başkanlı̆̆g,2020, URL Adresi: https://www.afad.gov.tr/aciklamali-afet-yonetimiterimleri-sozlugu, Erişim Tarihi: 08 Şubat 2021

Demirel, M., (2019). Eskiçağ Ön Asya Toplumlarında Görülen Salgın Hastalıklar, Yüksek Lisans Tezi, Gazi Üniversitesi, Ankara.

Dünya Sağlık Örgütü (WHO), İnternet Erişim Adresi: https://covid19.who.int/ İnternet Erişim Tarihi: 28 Şubat 2021

Kardaş, T., (2010). XIX. Yüzyılda Kafkasya'da Salgın Hastalıklar ve Karantina Önlemleri (1800- 1900), Yüksek Lisans Tezi, Ege Üniversitesi, İzmir.

Öğünç, K., (2020). Aile Hakimlerinin Covid-19 Pandemisi Sürecinde Yaşadıkları Sorunlar Ve Çözüm Önerileri: Niteliksel Bir Araştırma, Uzmanlık Tezi, Sakarya Üniversitesi, Adapazarı. 
Tercan, B., (2020). Biyolojik Afetler ve COVID-19. Paramedik ve Acil Sağlık Hizmetleri Dergisi, 1 (1) , 41 -50 . Retrieved from https://dergipark.org.tr/tr/pub/pashid/issue/54395/745994

T.C. Aile, Çalışma ve Sosyal Hizmetler Bakanlığı, İşyerlerinde Koronavirüsten (Covid- 19) Korunma Tedbirleri, İnternet Adresi: https://ailevecalisma.gov.tr/media/42190/covid-19-isyeri_korunma_tedbirleri_afis-a3boyutu.pdf Erişim Tarihi: 13 Şubat 2021

T.C. Cumhurbaşkanlığı Dijital Dönüşüm Ofisi, İnternet Erişim Adresi: https://corona.cbddo.gov.tr/ İnternet Erişim Tarihi: 28 Şubat 2021

T.C. İçişleri Bakanlığı Afet ve Acil Durum Yönetimi Başkanlığı, Açıklamalı Afet Yönetimi Terimleri Sözlüğü, İnternet Adresi: https://www.afad.gov.tr/aciklamali-afet-yonetimi-terimleri-sozlugu Erişim Tarihi: 13 Şubat 2021

T.C. Sağlık Bakanlığı, Covid-19 Bilgilendirme Sayfası, İnternet Adresi: https://covid19.saglik.gov.tr/TR66935/genel-koronavirus-tablosu.html Erişim Tarihi: 24.02.2021

Uçan, R., (2021). İSG Kayank Kitabı, Efe Akademi Yayınevi

Yönetmelik, İşyerlerinde Acil Durumlar Hakkında Yönetmelik, Resmî Gazete Tarihi 18.06.2013 Sayısı 28681

Yönetmelik, İş Sağlığı ve Güvenliği Risk Değerlendirmesi Yönetmeliği, Resmî Gazete Tarihi 29.12.2012 Sayısı 28512

Yönetmelik, Çalışanların İş Sağlığı ve Güvenliği Eğitimlerinin Usul ve Esasları Hakkında Yönetmelik, Resmî Gazete Tarihi 15.05.2013 Sayıs 28648

Yükseköğretim Kurulu, 2020, Yök’ten Koronavirüs (Covid-19) Hakkında Yükseköğretim Kurumlarında Alınacak Tedbirlere İliş̧kin Öneriler, İnternet Erişim Adresi: https://covid19.yok.gov.tr/Documents/alinankararlar/01-coronaviruse-iliskin-alinacak-onlemler.pdf İnternet Erişim Tarihi: 02 Şubat 2021

Yükseköğretim Kurulu, 2020, Koronavirüs (Covid-19) Bilgilendirme Notu: 1, İnternet Erişim Adresi: https://covid19.yok.gov.tr/Documents/alinan-kararlar/02-coronavirus-bilgilendirme-notu-1.pdf İnternet Erişim Tarihi: 02 Şubat 2021

Yükseköğretim Kurulu, 2020, Yükseköğretim Kurumlarımızdaki 2020-2021 Eğitim ve Öğretim Dönemine Yönelik Açıklama, İnternet Erişim Adresi: https://covid19.yok.gov.tr/Documents/alinan-kararlar/02-coronavirusbilgilendirme-notu-1.pdf İnternet Erişim Tarihi: 02 Şubat 2021

Yükseköğretim Kurulu, 2021, İstatistik, URL Adresi: https://istatistik.yok.gov.tr/, Erişim Tarihi: 26 Nisan 2021

\section{Conflict of Interest / Çıkar Çatışması}

Yazarlar tarafından herhangi bir çıkar çatışması beyan edilmemiştir.

No conflict of interest was declared by the authors.

\section{EK}

- Anket Soruları 
Tablo EK- Anket Soruları

\begin{tabular}{|c|c|}
\hline \multirow{9}{*}{ Unvan } & Profesör Dr. \\
\hline & Profesör \\
\hline & Doçent Dr. \\
\hline & Doçent \\
\hline & Dr. Öğretim Üyesi \\
\hline & Öğretim Görevlisi Dr. \\
\hline & Dr. \\
\hline & Öğretim Görevlisi \\
\hline & Araştırma Görevlisi \\
\hline \multirow{5}{*}{ Yaş } & $20-30$ \\
\hline & $31-40$ \\
\hline & $41-50$ \\
\hline & $51-65$ \\
\hline & $>65$ \\
\hline \multirow{2}{*}{ Medeni Durum } & Bekar \\
\hline & Evli \\
\hline \multirow{3}{*}{ Eğitim Durumu } & Lisans \\
\hline & Yüksek Lisans \\
\hline & Doktora \\
\hline \multirow{2}{*}{ Görev Alınan Yükseköğretim Kurumu } & Devlet Üniversitesi \\
\hline & Vakıf Üniversitesi \\
\hline \multirow{3}{*}{ Çalışma Şekli } & Tam Zamanli \\
\hline & Yarı Zamanlı \\
\hline & Ders Saat Ücretli \\
\hline \multirow{5}{*}{ Görev Alınan Birim } & Rektörlük \\
\hline & Enstitü \\
\hline & Fakülte \\
\hline & Yüksekokul \\
\hline & Meslek Yüksekokulu \\
\hline \multirow{2}{*}{ Görev Aldığı Birimde İdari Görev } & Var \\
\hline & Yok \\
\hline \multirow{3}{*}{$\begin{array}{l}\text { Türkiye' de COVID- } 19 \text { (Yeni Korona Virüs Hastalığı) teşhisi konulduğu } \\
\text { tarih (11 Mart 2020) öncesinde ilgili virüse ilişkin öğretim elemanları- } \\
\text { idari personel- öğrenci ve ziyaretçilere yönelik bilgilendirme/ eğitim } \\
\text { yapıldı mı? }\end{array}$} & Evet \\
\hline & Hayır \\
\hline & Bilmiyorum \\
\hline \multirow{3}{*}{$\begin{array}{l}\text { Türkiye' de COVID- } 19 \text { (Yeni Korona Virüs Hastalığı) teşhisi konulduğu } \\
\text { tarih (11 Mart 2020) öncesinde ilgili virüse ilişkin koruma önlem ve } \\
\text { tedbirleri (dezenfektan, hijyen vb.) belirlenerek uygulandı mı? }\end{array}$} & Evet \\
\hline & Hayır \\
\hline & Bilmiyorum \\
\hline \multirow{3}{*}{$\begin{array}{l}\text { Türkiye' de COVID- } 19 \text { (Yeni Korona Virüs Hastalığı) teşhisi konulduğu } \\
\text { tarih (11 Mart 2020) sonrasında ilgili virüse ilişkin çeşitli yollarla } \\
\text { korunma ve önleme özelinde bilgilendirme ve eğitim yapıldı mı? }\end{array}$} & Evet \\
\hline & Hayır \\
\hline & Bilmiyorum \\
\hline \multirow{3}{*}{$\begin{array}{l}\text { Türkiye' de COVID- } 19 \text { (Yeni Korona Virüs Hastalığı) teşhisi konulduğu } \\
\text { tarihten (11 Mart 2020) anketi doldurduğunuz güne değin üniversiteniz } \\
\text { yetkili kurumları tarafından sağlığınızın takibine yönelik herhangi bir } \\
\text { yolla geri bildirim istendi mi? }\end{array}$} & Evet \\
\hline & Hayır \\
\hline & Bilmiyorum \\
\hline \multirow{3}{*}{$\begin{array}{l}\text { Görev aldığınız üniversite COVID- } 19 \text { (Yeni Korona Virüs Hastalığı) } \\
\text { Salgını kaynaklı acil durum sürecini yönetmekte başarılı mıydı? }\end{array}$} & Evet \\
\hline & Hayır \\
\hline & Bilmiyorum \\
\hline
\end{tabular}

